\title{
Analytical Foundations of Erik Lindahl's Monetary Analysis, 1924-30
}

by

\author{
Claes-Henric Siven ${ }^{*}$
}

(2000-08-14)

\begin{abstract}
An overview is first given of Erik Lindahl's works during the 1920s: Aims of Monetary Policy, "The Place of Capital in the Theory of Price", "On the Relationship between the Quantity of Money and the Price Level" and Means of Monetary Policy. After that the origin of ideas and Lindahl's analytical contributions to monetary analysis during the 1920s is discussed from the following perspectives: the formulation of a norm for monetary policy, type of equilibrium analysis, fundamental equations and microeconomic foundations, capital theory and intertemporal analysis, assumptions about the monetary system, the stability problem and the uniqueness of the price level.
\end{abstract}

Keywords: Economic History, Monetary Theory, Wicksell, Lindahl.

JEL Classification: B22, B30, E 40.

\footnotetext{
* Correspondence may be addressed to Professor Claes-Henric Siven, Department of Economics, Stockholm University, S-106 91 Stockholm, Sweden. I wish to thank Karl-Olof Faxén, Hans-Michael Trautwein and two anonymous referees for valuable comments.
} 


\title{
Analytical Foundations of Erik Lindahl's Monetary Analysis, 1924-30
}

by

\author{
Claes-Henric Siven ${ }^{*}$
}

(2000-08-14)

Erik Lindahl might nowadays be most well-known for the Lindahl solution in public finance analysis, originally to be found in his dissertation Die Gerechtigkeit der Bestuerung from 1919. It has not always been that way. In his obituary over Lindahl, Ohlin $(1960,4)$ wrote, "His dissertation has since long been considered a bit obsolete $[\ldots]$ " but stressed the importance of Lindahl's monetary studies. ${ }^{1}$

Lindahl was a leading figure in the group that later was called the Stockholm School, compare Ohlin (1937a and 1937b) and Hansson (1982). One of the reasons for Lindahl's importance was that he carried on the tradition from Knut Wicksell. His work formed a major link between Wicksell and younger Swedish economists. ${ }^{2}$

Wicksell heavily influenced Lindahl's early scientific work. Lindahl's dissertation of 1919 was based on Wicksell's analysis in Finanztheoretische Untersuchungen.

Wicksell was also the opponent appointed by the faculty when Lindahl defended his

\footnotetext{
* Correspondence may be addressed to Professor Claes-Henric Siven, Department of Economics, Stockholm University, S-106 91 Stockholm, Sweden. I wish to thank Karl-Olof Faxén, Hans-Michael Trautwein and two anonymous referees for valuable comments.

${ }^{1}$ Ohlin's assessment was given in the midst of the Keynesian era. The renewed interest in policy norms and expectations during the 1970s and 1980s makes Lindahl's contributions even more interesting, see Velupillai (1988), Leijonhufvud (1991) and Fregert (1993).

${ }^{2}$ For discussions of Lindahl's life and work, see Herz (1959), Ohlin (1960), Svennilson (1960), Turvey (1960), Lundberg (1980 [1995]), Steiger (1987a) and Petersson (1989). Yohe (1962) stresses Lindahl's central place in the Wicksellian tradition in Sweden.
} 
dissertation. Lindahl's monetary work was moreover deeply influenced by Wicksell. In the beginning the direct contact remained -- Wicksell had read and commented upon the manuscript of Lindahl's (1924 [1929]) first major monetary work and also supported Lindahl when the latter applied for a professorship in Copenhagen (later to be given to Bertil Ohlin). In Stockholm Lindahl and Wicksell had contact through the Political Economy Club, see Henriksson (1991). Compare also the correspondence between Lindahl's works in monetary theory and policy, Ends of Monetary Policy and Means of Monetary Policy, respectively, with the title of Wicksell's inaugural lecture from 1904, "Ends and Means in Economics", Wicksell (1904).

Lindahl's formulation of the ends of monetary policy was closer to Davidson's approach than to that of Wicksell. But Lindahl built his positive analysis on the Wicksellian foundation. This concerns both microeconomics and the stress on variations of interest rates as monetary measures.

Lindahl consequently built his theoretical work on the Wicksellian tradition. But his development of the basic ideas was not only fruitful in itself. In addition it formed a platform for further development by other Swedish economists. Uhr (1960), Chiodi (1991) and Steiger (1987b) have discussed an important aspect of this influence. This concerns Lindahl's monetary theory as a starting point for Myrdal's analysis of monetary equilibrium. Myrdal started from Lindahl's discussion of the concept of the normal rate of interest. But the purpose of Lindahl's discussion was rather to motivate why he did not use the concept in his analysis. Furthermore, Lindahl's application of the temporary equilibrium method to monetary analysis influenced Hicks and via Hicks theoretical developments during the 1970s and 1980s.

Landgren (1960) started from a Keynesian perspective ${ }^{3}$ in his evaluation of Lindahl's monetary analysis. Landgren's approach was rather one-sided. This created reactions by Fernholm (1960), Lindahl (1960) and Steiger (1971).

\footnotetext{
${ }^{3}$ Two citations might exemplify Landgren's use of Keynesian economics as a norm when evaluating Lindahl's works: "It is an essential property of a macroeconomic theory that it uses national income as a variable." (Landgren 1960, 126) and "That national income would be depressed by a too strong liquidity preference is a development which seems to be outside Lindahl's vision." (Landgren 1960, 130).
} 
Petersson (1987 and 1991) focus on Lindahl's theory, but the concern is Lindahl's development of the general dynamic theory from the middle and end of the 1930s and its significance for the "late Stockholm School". Yohe (1962) deals with Lindahl's works after 1939. In contrast, Fregert's (1993) analysis of Lindahl's norms for monetary policy is more central for the present discussion, but Fregert's objective was not to discuss Lindahl's monetary analysis. Hansson (1982), Myhrman (1991) and Laidler (1999) are of more direct relevance for the present discussion, which deals with Lindahl's development of monetary theory during the 1920s. Laidler (1999) discusses Lindahl's role in the development of the Stockholm School. Myhrman (1991) gives a short survey of the monetary economics of the Stockholm School. Hansson (1982) contains an extensive discussion of Lindahl's development of the method of temporary equilibrium as a background to his monetary theory.

The earlier discussion has thus partly focused on other aspects than Lindahl's development of monetary theory during the 1920s. This is the task of the present paper: to discuss the analytical instruments used by Lindahl in his development of monetary theory during the 1920 s and to trace the origin of ideas concerning these instruments. ${ }^{4}$

I first give a general overview of Lindahl's work during the 1920s. The main part of the paper contains a discussion of Lindahl's analytical contributions to monetary analysis and of where he got the ideas for the theoretical development. This discussion starts from the following perspectives: the formulation of a norm for monetary policy, type of equilibrium analysis, fundamental equations and microeconomic foundations, capital theory and intertemporal analysis, assumptions about the monetary system, the stability problem and the uniqueness of the price level. To put Lindahl's contribution into perspective, the penultimate section contains a comparison between the analyses of Lindahl and Hicks of money under temporary equilibrium as well as a short reference to later developments. A summary and conclusion ends the paper.

\footnotetext{
${ }^{4}$ I will not discuss Lindahl's analysis of Wicksell's criteria for monetary equilibrium. This is best done in connection with Myrdal's development of monetary equilibrium.
} 


\section{Four works on monetary theory}

The following discussion deals with four works on monetary theory and policy published in $1924-30 .^{5}$

\section{Ends of Monetary Policy}

Penningpolitikens mål (Ends of Monetary Policy, hereafter Ends) was first printed in a few copies in 1924 when Lindahl applied for a professorship in Copenhagen. It was planned to be included in a work called Penningpolitikens mål och medel (Ends and Means of Monetary Policy, hereafter Ends). It was reprinted ${ }^{6}$ in 1929 parallely with Penningpolitikens medel (Means of Monetary Policy, hereafter Means), but the works were published as two separate books.

Lindahl motivated the choice of subject in the following way. Before World War I there was not much room for monetary policy. The main concern was to follow the rules of the gold standard. Now (1924) circumstances were different. According to Lindahl, it was therefore important to fix the rules of a rational monetary policy. It is somewhat paradoxical that the gold standard was reinstated in a number of countries (Sweden included) at almost the same time as the publication of Ends. However, Lindahl might have thought that even if the gold standard was reinstalled, this might not imply that the old rules were followed. Wicksell (1922 [1986, 191-2]) had argued that

[...] the old blind faith in the intrinsic invariability of the value of gold has now finally taken a beating, from which it is not likely to recover very easily. Indeed, both during and since the War the value of gold has submitted unresisting as yielding wax to the developments in the means of credit, so that one has every justification in saying that the present-day value of gold is quite simply the value of the dollar [...] So, if the metal gold is once more to become a common standard of value, then it will be absolutely necessary [...] to establish rules capable of regulating the value of this standard itself and to

\footnotetext{
5 Lindahl (1925) contains a discussion of the effects on the allocation of resources, integration of firms et cetera of the existence of short term credit in a society. Even if the effects are related to lower cash balances, the article is of only peripheral interest in the present context.
} 
confer upon it a stability which, if it is left to its own devices, it patently does not possess.

Lindahl stressed the importance of a clear goal for monetary policy in order to eliminate the need for the public to make guesses about the environment in which they act. A first goal of monetary policy was "by a consequent focus on a certain goal to guarantee the rule of law and confidence in economic life" (Lindahl 1924 [1929, 4]).

Lindahl's second norm for monetary policy was to aim at "a minimum of deviations between actual and intended outcomes of agreements in terms of money" (Lindahl $1924[1929,8])$ when the economy is subject to disturbances. This second norm forms the starting point for the discussion in the book.

The exact goal is of little importance according to Lindahl. A fully predicted slow inflation or slow deflation would for example not imply any drawbacks. Unexpected changes of productivity, especially permanent ones, should in contrast be parried by changes of the general price level in the opposite direction. ${ }^{7}$

Lindahl drew the conclusion that monetary policy must be conducted with firmness and consistency. It must be predictable. This implies more stable expectations of private agents, which in turn facilitates stabilization policy.

In Ends Lindahl thus stipulated a number of basic criteria (more fundamental than just a constant value of money) and asked how monetary policy by price level changes should react to different disturbances to best satisfy these criteria. Lindahl (1924 [1929]) did not discuss via which means the price level could be influenced. However, he announced that he was going to discuss this in Means.

\footnotetext{
${ }^{6}$ A few amendments were added.

${ }^{7}$ Lindahl started from productivity changes in the form of shifts of the production function so that the marginal and average productivities of all (dated) factors of production of all firms change by the same percentage.
} 
Ends is however not entirely concentrated on the goal problem but also contains some theoretical discussion in connection with the analyses of Wicksell and Davidson. For example, Lindahl (1924 [1929, 41-2]) observed that

[...] an unpredicted, permanent and proportional decrease of the productivity of all factors of production. [...] The [natural] rate of interest will be the same as before, since it is determined by the ratio between saved and current marginal productivities of land and labor. This ratio is not affected by a proportional decrease of productivity.

The observation has bearing on Wicksell's discussion of the effects of changes of the natural rate of interest. Wicksell often wrongly attributed changes of the natural rate of interest to changes of general productivity, see Siven (1997, 210-4 and 1998, 121 2). Lindahl $(1924[1929,5 \mathrm{n}])$ also observed that the demand for real balances is negatively influenced by a completely expected rate of inflation. ${ }^{8}$ A close parallel to this observation can be found in Brisman (1922, 1-2) and in Wicksell (1898a [1936, 119]). The discussion of chapter 3 of Ends furthermore contains observations on how disturbances create adjustment processes and thus points forwards to the analysis of Means.

The Place of Capital in the Theory of Price

"Prisbildningsproblemets uppläggning från kapitalteoretisk synpunkt" (The Place of Capital in the Theory of Price) from 1929 is perhaps Lindahl's most important work in economic theory. It contains the first systematic development of intertemporal microeconomic theory. It is true that Friedrich von Hayek's "Das intertemporale Gleichgewichtssystem der Preise und die Bewegungen des Geldwertes” from 1928 contains an earlier attempt to take the intertemporal perspective into consideration. But Hayek offered a less systematic exposition merely pointing out the analogy between interspacial and intertemporal pricing. In contrast to Lindahl's paper it offered no formal analysis of an intertemporal general equilibrium model. Moreover, it was partly directed to another question, namely the alleged necessity of price level

\footnotetext{
${ }^{8}$ Lindahl's observation constitutes the first component of the theory of the optimal quantity of money. The second component is that real balances should be determined so that marginal social costs and marginal social revenues of the quantity of money are equal, compare Friedman (1969).
} 
changes to uphold intertemporal equilibrium. It is also true that Fisher (1907 and 1930) develop intertemporal equilibrium analysis. But there is only one good so intercommodity relations were not analyzed, compare also Milgate $(1979,3)$.

Lindahl's paper also contains the first outline of temporary equilibrium theory. Unfortunately, Lindahl's name is neither mentioned in the two main surveys in the area, Grandmont (1977 and 1987), nor in Grandmont's (1983) summing up of monetary theory. The reason for this is probably that monetary analysis based on the temporary equilibrium method has been associated with Hicks' Value and Capital. Hicks' work was published in 1939 with a second and slightly amended edition in 1946. It had a great impact on the education of graduate economics students during the two first decades after World War II. However, Lindahl's works were not referred to in Value and Capital. But Hicks did refer to Lindahl in later works. ${ }^{9}$

In this 50 pages long article Lindahl outlined an extension of the Walras-Cassel general equilibrium model to cover several periods. In a series of sections he proceeded from the special (general equilibrium under stationary conditions) via intertemporal equilibrium to temporary equilibrium.

In all cases he assumed perfect competition and constant returns to scale in the production of all goods. Firms were assumed to maximize profits, but their behavior

\footnotetext{
${ }_{9}$ Hicks $(1965,58)$ mentions that "The first of the (properly) dynamic methods which I shall consider is that which was developed (very deliberately developed) by Erik Lindahl in 1929-30." Hicks (1965, 58n) further mentions that "I have myself been responsible (in parts III and IV of Value and Capital) for a 'dynamic' theory which claimed to be based on Lindahl's work. I then supposed that I was treading, quite closely, in Lindahl's footsteps; he himself held that we were further apart. As will be seen in what follows, I have become convinced, in the end, that he was right."
}

Hicks (1985) chapter 7 is devoted to the temporary equilibrium method. It is a revision of chapter IV of Hicks (1965). But the 1985 version gives more details about the influence of Lindahl on Hicks. Hicks (1985, 62n) mentions that "I do not read English, so my knowledge of the writings to which I am referring is limited. I did however make friends with Lindahl as early as 1933, and the substance of his Penningspolitikensmedel (1930) -- to appear in 1939 as the second part of his Studies in the Theory of Money and Capital -- was available to me from about the former date." Hicks $(1985,67-8)$ further gives the information that "I do not find it easy to proceed without some reference to the closely related theory which I gave myself in Value and Capital (based, as it was, upon conversations which I had had with Lindahl himself). The Value and Capital model is worked out in much greater detail than Lindahl's; for the sake of that detail I allowed myself a number of restrictive assumptions [...]".

In the preface to Lindahl (1939) the names of both John and Ursula Hicks are mentioned. It is evident that Lindahl in preparing his translation into English profited from the discussions with the Hicks 
was not derived from the maximization postulate. ${ }^{10}$ Their behavior equations were instead written down directly. The same was the case for consumers.

For the stationary case Lindahl presented the following equations. The Supply of the $n$ original factors of production ${ }^{11}$ and of the $m$ goods were written as functions of all factor and all goods prices, as well as the rate of interest. One of the $m$ goods demand equations is eliminated via Walras' law and the price of the first good (the numeraire) is normalized to unity.

The technical coefficients (for each good there are $n$ times $\tau$ technical coefficients, where $\tau$ is equal to the maximum lag between dated inputs and final output) are functions of the $n$ factor prices and the rate of interest. Since the $m$ aggregate production functions are linearly homogeneous, the quantities demanded of the $n$ original factors of production are given by the technical coefficients and the production quantities of the various goods.

The next subset of equations gives the $n$ equilibrium conditions for the $n$ original factors of production. Since production functions are linearly homogeneous, the supply functions for the $m$ goods are perfectly elastic so that the quantity produced is given by demand. The equilibrium conditions for the $m$ goods markets are therefore substituted for by the cost principle, that is the price for each good is equal to the discounted cost of producing the good. ${ }^{12}$

A final equation represents the quantity of circulating capital. Lindahl formulated it as to determine the average time, $T$, between inputs and outputs. The trick was to stipulate the same discounted cost in two situations: the first according to the actual structure of dated inputs (flow inputs, point output), the second for the hypothetical

couple. But nothing essentially new was added when translating Lindahl (1929a and 1930) into English.

${ }^{10}$ The equation system for the stationary case was actually a summary of the Walras-Cassel model of general equlibrium but extended to take the Wicksell-Austrian time structure of production into account. For this case is was consequently superfluous to derive the behavior equations. However, compare Cassel's argument against deriving demand functions from utility theory, see Magnusson (1991, 126-27).

${ }^{11}$ Since Lindahl stated from the Austrian theory of capital the time structure of production was not represented by capital goods but instead by dated inputs of the original factors of production (land and labor). 
case where all original factors of production lead output with $T$ periods (point input, point output).

The equations representing the cost principle and this last equation together imply that consumption is equal to total income. Here total income includes both incomes from original factors of production and interests.

Stationary equilibrium requires that all variables are constant over time. A shock hitting the general equilibrium system is however generally not expected immediately to result in a new stationary equilibrium. The analysis of stationary equilibrium consequently does not give a complete description of the reactions of the economy. A more general equilibrium concept, intertemporal equilibrium, is needed.

In intertemporal equilibrium endogenous variables generally obtain different values in different periods. Lindahl stressed (like Hayek one year earlier) that intertemporal equilibrium not only requires that the different markets in a certain period, but also between different periods, be built together in an interdependent system. This means that the agents plan their activities simultaneously for many periods ahead in time. Their expectations are consistent with the solution of the system.

The equation system for intertemporal equilibrium is consequently in principle an extension of the stationary system. The extensions are the following. Instead of a price vector for the current period plus a rate of interest, the price vector now contains the prices for each of the $t+1$ periods plus $t$ interest rates. Lindahl let the price of consumption good \#1 equal unity in each period. He could alternatively have deleted the interest rates and interpreted the prices in the periods after the initial period as discounted prices.

The equation system is extended to cover all $t+1$ periods, so in principle there are $t+1$ more equations than in the stationary case. In addition there are equations determining the saving of the households and how saving is reflected in changes of circulating capital.

${ }^{12}$ The same analytical layout can be found in the small general equilibrium model in Wicksell (1893). 
Since Lindahl (1929a) did not analyze forward markets, present prices in the current period and complete knowledge of prices of future periods coordinate the actions of all the agents. A comparison of Lindahl's (1929a) equation systems describing stationary and intertemporal equilibrium shows that the former equilibrium concept is a special case of the latter. A stationary equilibrium is an intertemporal equilibrium, but the converse does not necessarily hold.

Lindahl stressed that no unexpected events are allowed (Lindahl did not analyze contingent markets). Consequently, an even more general equilibrium concept is needed.

In temporary equilibrium expectations of the agents are required to be consistent with the solution of the system only for the current period. Since the agents plan for many periods ahead, the actions during the current period are influenced by the expectations of the future development. In a first version of the temporary equilibrium model, Lindahl assumed that expectations (like in intertemporal equilibrium) are subjectively certain. Moreover, they correspond to the true path of the exogenous and endogenous variables for the hypothetical case that no unexpected disturbances occur. The equation system for the intertemporal equilibrium model can thus be used for analyzing this version of temporary equilibrium.

However, in contrast to intertemporal equilibrium, unpredictable exogenous disturbances require plans to be redrawn in the beginning of each new period. All changes take place at the point of transition from one period of time to another. As discussed by Myrdal (1927) there will be (unexpected) capital gains or losses. In contrast to income which is defined for a period, capital gains and losses are defined for a point of time.

It is problematic to both assume subjectively certain expectations and recurrent unpredicted exogenous disturbances. This may be the reason why Lindahl outlined an alternative temporary equilibrium model where the agents no more have subjectively certain expectations. Expectations for the development after the first period are instead described by probability density functions, which may differ for different 
agents. As pointed out by Lindahl $(1929 a, 81)$ this general case is very difficult to analyze.

The article also contains discussions of the two different approaches to the theory of capital. The first possibility is to introduce capital by dating all inputs of primary factors of production (circulating capital). There might thus not only be joint input of different factors of production, but also of the same factor of production at different dates. This is the Austrian approach used by inter alia Böhm-Bawerk and Wicksell. The second possibility is the approach of Walras where the early inputs of primary factors of productions are collected in explicitly noted capital goods (fixed capital). These capital goods produce joint output over a number of periods. ${ }^{13}$ In his formal analysis Lindahl followed the first approach.

On the relationship between the quantity of money and the price level

"Om förhållandet mellan penningmängd och prisnivå" (On the relationship between the quantity of money and the price level) from 1929 is a short article published in a peripheral connection. The article contains a critical discussion of the quantity theory of money. Here Lindahl discussed the problem of aggregation from the point of view of different definitions of the volume of transactions, the quantity of money and the price level (and thus indirectly the velocity of transactions). He furthermore discussed the exogenity of the quantity of money. A main point (which reoccurs in Hansen $1955)$ is the impossibility to talk about the effects of changes of endogenous variables.

The article is important since Lindahl here motivates his critical attitude to the quantity theory of money. There is no correspondence to Wicksell's positive attitude in principle.

\footnotetext{
${ }^{13}$ Lindahl (1929a, 47) noted that Walras did not take varying durability of investment goods into consideration. This problem was analyzed in Åkerman (1923), but under quite restrictive assumptions (in a review of Åkerman's dissertation Wicksell (1923) had analyzed the same problem by using calculus.). The problem to analyze production with fixed capital of varying durability within a general equilibrium model still remained.
} 


\section{Means of Monetary Policy}

Penningpolitikens medel (Means of Monetary Policy) was printed ${ }^{14}$ in 1930. In Ends

Lindahl had mainly abstained from discussing how to achieve the monetary goals.

Means was devoted to this very task. Here Lindahl formulated a verbal

macroeconomic model, which was used for analyzing the effects of different

disturbances, and how these effects could be eliminated using different monetary

instruments. One of Lindahl's conclusions is that the monetary norm of a constant price level of consumption goods (supplemented with the rule that the price level varies inversely with productivity changes) not only satisfies his basic principles for monetary policy as formulated in Ends. It also leads to the simplest design of monetary policy (a minimum of interest rate changes). Means is the central source of Lindahl's theory of money. However, the three previous works give information about the development of Lindahl's thinking on monetary theory. Moreover, the analysis in Means is based on these three works.

Chapter 1 of Means describes the basic version of Lindahl's macroeconomic model. The payments system is characterized by:

\section{Closed economy}

2. Fiat money (no gold standard)

3. All bank loans are given by a single bank. This bank has also the right to create legal tender.

4. No cash holdings. Payments are effected via a giro system operated by the bank. All deposits in the bank earn the same rate of interest.

Assumptions 2-4 imply the existence of a system of pure inside money. ${ }^{15}$ In addition to the bank there is a household and a business sector. The marginal and average propensity to save is greater for entrepreneurs than for workers.

\footnotetext{
${ }^{14}$ A preliminary edition circulated already in 1929. The definitive edition of 1930 contains a few corrections to chapters 2 and 3 and in addition a chapter on international issues. The main part of the book was possibly written as early as 1927-28, see Hansen $(1981,261 n)$. Steiger $(1971,175)$ gives the information that Lindahl's equilibrium equation for the aggregate consumption market was presented verbally already in his lectures in the spring of 1925.

${ }^{15}$ For definitions of inside and outside money and a discussion of the implications of different monetary arrangements for the uniqueness and stability problems of the price level, see Patinkin (1965, 295-310) and Grandmont (1983). Compare also Gurley and Shaw (1960).
} 
The goods markets are divided into an aggregate consumption goods market and an aggregate capital goods market. There is only one explicit equation, the equilibrium condition for the aggregate consumption goods market:

(1) $E(1-s)=P Q$

Here $E$ denotes aggregate incomes, $s$ the average propensity to save, $P$ the average price level of consumption goods and $Q$ the supply of consumption goods.

The concept of income, $E$, that Lindahl used in equation (1) is the yield on assets owned by the private sector. Assets are widely defined (inter alia including human capital) ${ }^{16}$ :

[...] can income of a certain individual during a certain time period be calculated as interest on all assets owned by the individual, including the capital value of his own labor.

Lindahl (1930, $21[1939,147])$

This intertemporal concept of income is closely connected with the analysis of Lindahl (1929a) and of Myrdal (1927). However, Lindahl stressed that the exact definition of income is not important for the conclusions.

Like Wicksell (1906 [1935, 159-60]) Lindahl assumed that excess demand for goods at the original price level would increase prices. ${ }^{17}$ However, Lindahl stressed that

\footnotetext{
${ }^{16}$ Landgren $(1960,126)$ stressed the influence of Irving Fisher on Lindahl's concept of income. However, since Fisher's (1906; 1907 and 1930) definition of (real) income coincides with consumption is seems that the influence is more of an indirect nature. On the other hand, Fisher $(1906,184)$ stressed that income and capital were analogous concepts and that "all capital yields income and that all income flows from capital -- at least when the term "capital" is used in its broader sense, which includes human beings." Moreover, Lindahl's concept of capital (discounting of prospective income flows into capital) seems to be influenced by Fisher, compare Lindahl (1929a, 42-3).

17 "The [...] discussion is mainly based on the monetary doctrines which can be found in the works of Knut Wicksell. Wicksell's doctrine about the relationship between the loan rate of interest and the price level starts from the view that changes of the price level as well as changes of relative prices should be explained by the relationship between demand and supply of goods." (Lindahl 1930, 121 [1939, 245])
} 
equation (1) cannot be used in isolation to analyze the effects on the price level of different disturbances. The reason is that income, propensity to save and production are endogenous variables and are simultaneously determined in a system of equations where (1) constitutes but one of the equations:

A primary change [change of an exogenous variable] may immediately affect one or several of the pricing variables [endogenous variables]. These primary effects will then via the interdependence of pricing in different markets secondarily influence other endogenous variables, which were not affected in the first place.

Lindahl (1930, 15-16 [1939, 147])

In order to get a feeling of how the basic model functions, we will now discuss the effects of a permanent decrease of the rate of interest. This case is analyzed in chapter 2 of Means. Assume that the bank lowers the loan rate of interest. Saving is assumed to be relatively inelastic with respect to the rate of interest, compare Myhrman (1991) for an explanation in terms of Lindahl's intertemporal concept of income. The firms will on the other hand partly react by increasing their stocks, partly by demanding more capital goods. The former implies a temporary decrease of the supply of consumer goods, the latter an increased demand for capital goods. For both reasons consumer prices increase. Factors of production will be reallocated from the consumption goods to the capital goods sector. Factor prices and capital goods prices increase as well. This results in further increases of consumer goods prices and so on. In the absence of any inertia all prices in the current period would increase without limit, compare the assumption of pure inside money.

However, the development will not be explosive since wages are assumed to be sticky (Means, 40). ${ }^{18}$ This causes redistribution from workers with a low (average and marginal) propensity to save to entrepreneurs with a high propensity to save.

\footnotetext{
${ }^{18}$ A parallell is Keynes' $(1930,244)$ assumption of rigid factor prices. However, Keynes did not need the assumption to get stability if the price level. Compare also the question of forced saving. For a survey and application to Lindahl's analysis, see Hansson (1986).
} 
The generation of expectations and the knowledge of the environment play a central role in Lindahl's monetary works. If the agents had full knowledge of the development of the price level, there would be no role for monetary policy:

[If] the future was completely predicted [...] price level changes [...] would be primarily given in the sense that the anticipations of the agents about the future development of the price level to a certain extent makes this development of the price level come true. All other factors of equation (1) adjust to this anticipated development of the price level.

Lindahl (1930, 16 [1939, 147])

Monetary policy is thus not very interesting in intertemporal equilibrium. But even if the agents do not perfectly predict the future, expectations still play an important role for the development and thus for monetary policy:

In order for the price level to be constant another interest rate policy is required if the public believes in a constant price level than if they believe in an increasing or a decreasing price level.

Lindahl $(1930,28)$

In chapters 4 and 5 of Means Lindahl discussed the consequences of more general assumptions than those of his basic model. He introduced a banking sector with commercial banks and a central bank, interest rate differentiation, cash holding by households, a metal standard and finally monetary problems of an open economy under different exchange rate systems (including the gold standard). The less restrictive assumptions produce a richer flora of conclusions, but they do not fundamentally change the original results. One reason for this is that Lindahl did not analyze the implications of the real balance effect or internal and external drain. ${ }^{19}$ Both mechanisms had already been analyzed by Wicksell (1898a), so the idea was not very far-fetched, see Laidler (1991) and Siven (1997).

${ }^{19}$ The role of the real balance effect in Lindahl's monetary analysis has been discussed by Laidler (1998) and by Trautwein (1998). 
Two of the four works discussed above are translated into English and published in Lindahl (1939). Lindahl (1929a) is almost completely translated. However, Lindahl has modified the notation in his equations. To some extent this has also affected the text. Lindahl (1930) is only partly translated and new material marked by square brackets has been added. Even if the condensed translation gives a fair representation of the Swedish original, some relevant material has been condensed or deleted. ${ }^{20} \mathrm{My}$ discussion therefore starts from the Swedish original and the citations are taken and translated directly from this version. However, for the cases where translations of my citations can be found in the 1939 edition, they have been specially marked.

\section{The formulation of a norm for monetary policy}

During the two last years of the First World War inflation in Sweden was up to 40 percent a year. In the beginning of the 1920s inflation was followed by deflation. Consumer prices fell by 25 percent in 1921 and by 13 percent in $1922^{21}$. The great changes of the general price level were during the last war years accompanied by severe supply problems and in 1917 even hunger riots. During the years of deflation Sweden for a short time experienced heavy unemployment. In the beginning of 1922 unemployment among trade union members reached a maximum of 35 percent, see Fregert (1994, 284).

Sweden was not alone to experience monetary problems. In some countries, notably Germany, the first years of the 1920s were not marked by deflation but by hyperinflation. The economic problems of the post-war years increased the wish to go back to normal times, which inter alia meant a restitution of the gold standard.

Much of the monetary debate during the first post-war years concerned the question of a possible restoration of the gold standard. This was the case in Sweden as well as in many other European countries and in the USA. Keynes' A Tract on Monetary

\footnotetext{
${ }^{20}$ The main example of the first is the treatment of monetary policy in an open economy. The main example of the second case is the discussion of equilibrium unemployment and the stability of unemployment equilibrium in the preliminary edition of 1929. For comments of the latter aspect, see Hansen (1981, 261-63).

${ }^{21}$ Statistics Sweden $(1993,16)$.
} 
Reform of 1923 was a contribution to this debate. In Sweden there was a lively debate between Wicksell, Cassel, Heckscher and Silverstolpe about the pros and cons of reverting to the gold standard. ${ }^{22}$ Wicksell did not want a return to the gold standard but a system of fiat money. This system should be combined with a rule for monetary policy stipulating that the rate of interest should increase if prices went up and decrease in the opposite case. Wicksell thought that this rule should not be beyond the intellectual capacity of the bankers. The other Swedish economists thought that a return to the gold standard would to some extent be a guarantee against the monetary excesses during and after World War I. Their arguments, compare Östlind (1945, 3278), were similar to that given in Keynes $(1923,135)^{23}$ :

[...] this is the only way of avoiding the dangers of a 'managed' currency. It is natural, after what we have experienced, that prudent people should desiderate a standard of value which is independent of finance ministers and state banks.

When Lindahl wrote Ends the monetary turbulence of the past years was in fresh memory. However, he did not discuss whether a restoration of the gold standard would lead to better stability. As noted above, his starting-point was that the return to normal times would not mean a restoration of the classical rules of the gold standard. ${ }^{24}$ It was therefore necessary to discuss what rules should govern monetary policy in the future.

Lindahl's first goal of monetary policy, "by a consequent focus on a certain goal to guarantee the rule of law and confidence in economic life" (Lindahl 1924 [1929, 4]) must be seen against the background of the turbulent years just passed. Lindahl's second rule of "a minimum of deviations between actual and intended outcomes of agreements in terms of money" fits in the same scheme, or as Wicksell put it in the preface to the 1922 German edition of Lectures:

\footnotetext{
${ }^{22}$ For a survey of the Swedish discussion, see Östlind (1945, 326-8). Compare also Bianovsky (1998).

${ }^{23}$ Note that Keynes was not an advocate of the gold standard.

${ }^{24}$ The reason why the self regulating mechanism of the gold standard had to be substituted for by a system of managed money was that this system was already in effect after World War I and secondly that a possible restitution of the gold standard would not mean the same system as before the Great War. Wicksell thought that the fact that before the War gold circulated in the form of coins in England,
} 
With the present variability and uncertainty of all values, in other words, with the present legal uncertainty, as everyone must recognize, the whole of business life has been transformed into a pure game of chance. Hard work and honest efforts do not longer serve. [...] It has to be made clear from the start, both to debtors and to creditors, that the debtor will not be compelled to pay more or the creditor to accept less than the value of the sum agreed upon when the contract was effectuated. Only then will trust be restored and will it be possible to speak once more of healthy, and therefore successful business activity.

(Wicksell 1922 [1986, 194])

Taken literary, Lindahl's second rule implies not a constant price level but a development of the price level that conforms to expectations of the general public and to the publicly announced rule of monetary policy. As pointed out by Boianovsky (1998, 224-5) Wicksell had stressed the importance of conformity between monetary policy and the expectations of businessmen. Compare also Wicksell's (1898a [1936, 3]) statement of the neutrality of a completely foreseen inflation:

Moreover, if a gradual rise in prices, in accordance with an approximately known schedule, could be reckoned on with certainty, it would be taken into account in all current business contracts; with the result that its supposed beneficial influence would necessarily be reduced to a minimum. Those people who prefer a continually upward moving to a stationary price level forcibly remind one of those who purposely keep their watches a little fast so as to be more certain of catching their trains. But to achieve their purpose they must not be conscious or remain conscious of the fact that their watches are fast; otherwise they become accustomed to take the extra few minutes into account and so after all, in spite of their artfulness, arrive too late....

Boianovsky $(1998,266)$ also stressed that Lindahl's discussion of policy rules and publicly announced monetary policy can be traced to Wicksell's influence. But in 
addition, which is not so easy to derive from Lindahl's second rule for monetary policy, Lindahl stipulated that the price level should vary inversely to productivity.

The reason for this rule is to minimize business fluctuations ${ }^{25}$ : "In this way business fluctuations which are harmful for the economy as a whole are avoided [...]" (Lindahl 1924 [1929, 45]). Moreover: "The regulation of the general price level in inverse proportion to general productivity will consequently protect the firms from losses due to decreases of productivity to the extent that a general depression is counteracted. If productivity increases this norm for the value of money will correspondingly eliminate the possibility for firms to make profits at the expense of lenders." (Lindahl $1924[1929,54])$.

Fregert $(1993,130)$ has interpreted the rule as effectively eliminating the absence of equity markets by monetary policy:

Lindahl's preferred rule should shift systematic risk from the entrepreneurs to the debt holders, effectively transforming debt into equity. If investment were equity financed there would be no need to protect entrepreneurs against unforeseen shocks since capitalists would bear the whole burden. In this way, Lindahl assumes a market failure, the absence of an equity market. [...] By transforming debts to contingent claims through the feedback from productivity to prices, the government creates the missing equity market.

However, as stressed by Fregert, Lindah's rule only eliminates systematic risks, not particular productivity risks for individual firms. ${ }^{26}$ Moreover, it is only if all loans are transformed into equity that the interpretation is correct. But in this case there would be another market failure, the absence of a loan market.

\footnotetext{
${ }^{25}$ Note the similarity with Wicksell's (1908) thought that crises (but not the business cycle) could be avoided by a monetary policy aiming at stabilizing the prize level. In Lindahl's case of course the trick was to stabilize the price level in relation to general productivity. Compare Boinovsky (1995).

${ }^{26}$ Similar observations regarding the impossibility of protecting firms from risks related to fluctuations of relative prices can be found in Wicksell $(1908,212)$ and Keynes $(1923,33)$. In addition to the translation in Wicksell $(1999,36)$, a translation of the relevant passage of Wicksell (1908) can be found in Boianovsky $(1995,398)$.
} 
Fregert $(1993,136)$ also argued that sticky wages would be another argument for Lindahl's rule of letting the price level vary in opposite proportion to productivity. Textual evidence can be found in Lindahl $(1924$ [1929, 63]). The same argument was given by Myrdal (1931, 241).

Lindahl's analysis of the choice of norm for monetary policy was not only influenced by current monetary experiences and by the monetary debate in the beginning of the 1920s. It also built on a long discussion between Wicksell and Davidson. This debate started the year after the publication of Prices and Interest. Wicksell thought that the value of money should be stable. Davidson had the same opinion as Wicksell except that the price level should vary in inverse proportion to general productivity.

Davidson's discussion with Wicksell about monetary norms (constant price level or something else) concerns a special aspect of stabilization policy. What should be stabilized? Wicksell only pointed out the price level. Davidson first introduced a distributional argument (1899), then an efficiency argument (1906). Davidson (1919, 233-35), Davidson (1922, 103-4) and Davidson (1923, 233) advanced a third argument for his norm based on a Ricardian absolute cost theory. Davidson (1906, 467) contains an early statement in this direction. To a certain extent this means that the discussion concerned several goals. But Davidson's arguments converged in the same rule for the development of the price level and therefore in one intermediate goal. $^{27}$

Lindahl was also to some extent influenced by Hayek ${ }^{28}$. Lindahl $(1930,11 \mathrm{n})$ referred to Hayek (1928). Furthermore Hayek (1929 [1933, 115n]) noted that his monetary program was similar to that of Davidson, but complained that he was not able to read Swedish. There is also a possible indirect link. The discussion of bimetallism in the late 19th century concerned norms for monetary policy (rules of game and the automatic functioning of different monetary systems). Whereas monometallists tended to prefer a stable nominal wages level, bimetallists preferred a stable price level, compare Walsh (1903), Mason (1982) and Selgin (1995). If the real rate of

${ }^{27}$ For a survey of the discussion between Wicksell and Davidson, see Hammarskjöld (1944 [1955]) and Siven (1998). 
interest were independent of the development of the price level it seems that the factual difference between the two positions would be negligible. But as Fisher (1896: 54-76) had demonstrated, the nominal rate of interest did not fully adjust to variations of the rate of inflation.

Both Davidson and Wicksell might have been influenced by this discussion. Wicksell originally planned to write a book on the bimetallic question, compare Wicksell (1898a [1936: xxiii]). It is interesting to note that Wicksell $(1898 b$ [1958, 69]) considered "that most modern economists, with the exception of a small group, mainly bimetallists [who like Wicksell favored a stable price level], who in spite of everything still adhere to the quantity theory, lack any real, logically worked out theory of the value of money and its causes".

In Davidson's case I do not know of any direct connection. However, the influence of Ricardo (according to Walsh (1903, 59-61) favoring money stable in wages) on Davidson is evident. ${ }^{29}{ }^{30}$ Moreover, both Lindahl (1924 [1929, 29n]) and Hayek (1928 [1984, 100n]) refer to Walsh's (1903) survey $^{31}$ of the economic discussion concerning different monetary systems.

\section{Type of equilibrium analysis}

Different types of equilibrium analysis are discussed in Lindahl (1929a). However, already in Ends the interest was focused on situations where the agents do not have complete knowledge of their environment (for example of the level of productivity during the periods covered by a contract in terms of money). According to Lindahl, this is the very reason why monetary policy is needed -- to decrease the volatility of profits and thereby to decrease the amplityde of the business cycle. This uncertainty cannot exist in stationary or intertemporal equilibrium, but it appears in temporary

\footnotetext{
${ }^{28}$ For a discussion of the development of Hayek's views on the norm for monetary policy (and a comparison with those of Keynes), see Selgin (1999).

${ }^{29}$ For discussions of Davidson's interest in Ricardo's theories, see Thomas (1935), Heckscher (1951) and Uhr (1975).

${ }^{30}$ Compare also Davidson's third argument for his norm mentioned above.

${ }^{31}$ Walsh (1903) was highly regarded by both Hayek (1928 [1984, 100n]) and Schumpeter (1954, 1092).
} 
equilibrium. One can thus say that the problems studied by Lindahl in his monetary works to a certain extent influenced the choice of type of equilibrium analysis.

Earlier Swedish economists started from stationary equilibrium or from some form of equilibrium analysis, which was not specified in detail. Gustav Cassel's uniformly progressive economy (a verbal predecessor of the Harrod-Domar model of growth) was naturally a generalization from stationary to steady state equilibrium, compare Cassel (1918, 27-34), Magnusson (1991, 130-1) and Siven (1985). Moreover, in spite of the fact that Wicksell meant stationary equilibrium when he used the term equilibrium he analyzed more general equilibrium situations in his cumulative process. In Wicksell (1898a [1936, chapter 9, section B]) Wicksell worked with sequential clearing of the labor and the goods market within the period, compare Siven (1997). In other parts of Interest and Prices (for example chapter 8) Wicksell might have thought of simultaneous clearing of all markets within the period. ${ }^{32}$ However, verbal precision was not very high and it was first with the systematic discussion in Lindahl (1929a) that the correspondence between the different equilibrium concepts was clarified.

For temporary equilibrium to exist the actions of the individuals only have to be coordinated in the current period. If an economy in intertemporal equilibrium is hit by a disturbance, it may take many periods before the agents have aquired the necessary knowledge about the environment so that the perfect foresight, which is necessary for intertemporal equilibrium, is reached again (if ever). During the transition there will be temporary equilibrium in each period.

From Lindahl's (1929a) formal analysis it is clear that intertemporal equilibrium is a special case of temporary equilibrium. In comparison to the version of temporary eqilibrium where all individuals have the same subjectively certain expectations for the future development, intertemporal equilibrium in addition requires these expectations to be intertemporally consistent. In the same way, other versions of temporary equilibrium have intertemporal equilibrium as a special case. For exemple,

\footnotetext{
${ }^{32}$ Compare Bailey (1976, 67). Moreover, Hicks (1946, 252-3) described Wicksell's cumulative process from the point of view of temporary equilibrium with simultaneous clearing of all markets. The solution implies "correct" relative prices but an indeterminate price level.
} 
this is the case for the second version of temporary equilibrium in Lindahl (1929a). If we let all individuals have the same probabilistic expectations, let the probability mass of these multivariate probability density distributions collapse in a single point and finally let this point be the same for all individuals, the first version of temporary equilibrium in Lindahl (1929a) is obtained as a special case of the second version. The different versions of temporary equilibrium vary because of varying assumptions about the expectation function. The conclusion that intertemporal equilibrium is a special case of the second version of temporary equilibrium then follows immediately.

The transition from intertemporal to temporary equilibrium ${ }^{33}$ is still compatible with intertemporal planning from the part of individual agents, but they are now subject to surprises so that expectations in a certain period about the future development will not necessarily be fulfilled:

When analyzing a dynamic process we divide it into short time periods so that exogenous variables as well as prices can be viewed as constant during each time period. All changes are assumed to happen during the transition from one period to another. The development of prices can then be represented as a succession of pricing situations. We further assume, that the individuals during each of these short periods have full knowledge of the current prices, and that their supply and demand actions are determined by these prices, which consequently are generated as a result of the actions mentioned above. Pricing will then be characterized as equilibrium situations in the sense that there is equilibrium between supply and demand during the period. Pricing can then during each period be represented by a system of equations. [Footnote 1: In contrast to the situation when the future is completely foreseen, the equation systems for each of the periods cannot be integrated into a uniform system. Due to actual disturbances, which were only predicted as risks and chances, a new equation system must be constructed for each period.] The changes of the individual prices and of the price level from one period to another depend on the changes of exogenous variables. These events take place in the transition

\footnotetext{
${ }^{33}$ The latter term can be found in the English version from 1939, but not in the Swedish original from 1930. However, according to Hansson $(1982,68)$, Lindahl used the term in a letter to Ragnar Frisch of October $23^{\text {rd }}, 1934$.
} 
from one period to another. A change of the price level is consequently connected with changes of the factors, which are included in the expression $\mathrm{E}(1-\mathrm{s}): \mathrm{Q}$.

Lindahl (1930, 31-32 [1939, 158-59])

To sum up, there is a hierarchy of equilibrium concepts where stationary equilibrium is a special case of intertemporal equilibrium, which in turn is a special case of temporary equilibrium. This means inter alia that intertemporal equilibrium is a temporary equilibrium. In temporary equilibrium the actions of all economic agents are coordinated during the present period, but not necessarily during future periods. Nevertheless, the agents plan for future periods and their actions during the present period are influenced by their plans for the future, compare for example the intertemporal interpretation of the income variable, $E$.

Why did Lindahl (1930) use temporary equilibrium, not a more restrictive equilibrium concept, which would be easier to handle? Hansson $(1982,24-5)$ has suggested that there is an analytical reason for working with temporary equilibrium in monetary analysis:

It is important to notice that the analysis pursued within this method must be in real terms; i.e. it is a barter economy, and no commodity may therefore serve solely as a medium of exchange, because in the case of perfect foresight, where the different plans are compatible but new contracts will actually be signed over the whole sequence, there is no reason to hold a commodity in the terminal period which has no direct utility as a medium of exchange, and since no further exchange takes place it has no indirect utility either. In the case of complete future markets, where the plans are reconciled before the process starts, no new contracts are signed during the sequence. The process of reconciliation by which the equilibrium is established is therefore, if it is discussed at all, supposed to have a notional character, which means that no deals are concluded before all the plans are consistent, and in such a process a medium of exchange is superfluous. Hence, in both cases any good may serve 
as numeraire, which is just a convenience for expressing all the different exchange rates in a common unit. However, several practitioners have proceeded as if fiat money was included in intertemporal equilibrium or they have made analogies to a money economy.

The first case (perfect foresight) according to Hansson's argument presupposes a finite horizon. However, even of Lindahl did not give a strict definition, it does seem that he had an infinite horizon in mind:

We assume that the $t: t h$ [=last] period is so far away that circumstances after this period is of no relevance for pricing during the periods under investigation. The situation during these earlier periods of the dynamic process would consequently not change if the economy entered stationary conditions from period $t$ and onwards.

Lindahl (1929a, 63 [1939, 322]).

Hansson's second case (a complete set of forward markets) is not applicable to Lindahl's analysis since the latter did not analyze forward markets. However, Hansson's argument can equally well be applied to temporary equilibrium since general equilibrium for the period under study might be created by a tâtonnement process. In a tâtonnement process no transactions are actually carried out before the price system clears all markets.

The existence of a monetary economy (a positive value of fiat money) was examined during the 1970s and 1980s, compare Grandmont and Younes (1972), Grandmont (1974) and Grandmont (1983). A major condition for a positive value of money in temporary equilibrium is that the agents expect the value of money to be positive in future periods as well. This assumption of expectations is formulated within a model where money is assumed to fulfill the role of intertemporal transmission of purchasing power. The existence of a positive value of fiat money under steady state -- a special case of intertemporal equilibrium -- is discussed in Grandmont (1983), chapter 3. The agents are assumed to have perfect foresight and the role of money is to transfer 
purchasing power between periods. The analysis of the functioning of money is thus not focused on its role in the exchange process. Various types of monetary economies are shown to exist, but there are also cases when the value of money is zero.

The conclusion is that it is not necessary to assume temporary instead of intertemporal equilibrium to prove the existence of a monetary economy with fiat money. So this is not the reason for Lindahl's use of temporary equilibrium in his monetary analysis -if he had had a presentiment of the results of this modern research. However, in the absence of a motivation from Lindahl himself we can only suggest a likely explanation. The main reason was probably relevance. Lindahl's second norm for monetary policy was to aim at "a minimum of deviations between actual and intended outcomes of agreements in terms of money". But an unbroken intertemporal equilibrium does not leave room for unexpected events, compare the citation from Lindahl (1930, 16 [1939, 147]) above.

In temporary equilibrium expectations of the agents are correct for the first period. This is in contrast to intertemporal equilibrium where expectations are correct for all periods up to the horizon. If we define rational expectations as consistent with the model describing the economy, it is tempting to draw the following conclusion: Expectations are rational under intertemporal equilibrium, but not under temporary equilibrium. Lundberg $(1930$ [1995, 34]) argued in the same direction: "the assumption that individuals' expectations are 'rational', in the sense that they are realized, is identical with Lindahl's hypothesis that the future is wholly foreseen". However, the requirement of model-consistency for expectations to be rational might also be fulfilled under temporary equilibrium. Lindahl's alternative temporary equilibrium model where the expectations for the development after the first period are described by probability density functions is an example. The requirement is that all agents have the same expectations and that the successive conditional probability density functions describing their expectations and the development of the economy, respectively, co-inside. ${ }^{3435}$

\footnotetext{
${ }^{34}$ The original development of rational expectations theory of Muth (1961) and Lucas (1972) explicitly referred to a stochastic economy. Compare further an early survey by Schiller (1978) where he notes that correct expectations of the mean but not of the other moments of the probability density function is usually assumed.
} 


\section{Fundamental equations and microeconomic foundations}

Several authors have noticed that there is a similarity between Keynes' (1930) fundamental equations and Lindahl's (1930) equilibrium condition for the aggregate consumption goods market. Landgren $(1960,127)$ considered Lindahl's equation (1) as an identity of the same type as used in exchange equation or as in Keynes' Treatise. Hansson $(1982,53)$ noted that Lindahl's formulation "is almost identical to Keynes' fundamental equations".

The similarity between Lindahl's and Keynes' formulations is appearant at a quick glance. Whereas Lindahl's equation as already noted is formulated as $E(1-s)=P Q$, Keynes' first fundamental equation (the second fundamental equation gives an analogous expression for investment goods) reads $P R=E-S$. So in both cases the price of consumption goods times its quantity should be equal to consumption.

However, there is a big difference. Whereas Keynes' formulation implies two different ways of writing the (monetary) demand for consumption goods and consequently constitutes an identity, Lindahl's equation is an equlibrium condition for the aggregate consumption goods market. This means that in Lindahl's case $Q^{36}$ should be interpreted as supply of consumption goods whereas in Keynes' case $R$ should be interpreted as demand for consumption goods. That Keynes fundamental equations should be conceived of as identities have been noted by Keynes $(1930,138)$ and Dimand (1986).

The distinction between Keynes' identity and Lindahl's equilibrium condition is however blurred by the fact that Keynes introduced assumptions about the functional dependence on the variables of the fundamental equations of the rate of interest and of windfall profits. But Keynes did not develop this analysis on the basis of an explicit microeconomic equation system. What about Lindahl?

\footnotetext{
${ }^{35}$ For a further discussion of rational expectations in connection with Lindahl, and of Irving Fishers influence on Lindahl (and Myrdal) in this connection, see Laidler (1999, chapter 3).

${ }^{36}$ See Lindahl (1930, 24 [1939, 156]).
} 
Lindahl $(1930,12)$ stated that his equation $E(1-s)=P Q$ was derived from the first of the microeconomic equations (referring to the first period) in Lindahl (1929a, 68). ${ }^{37}$ This equation does not contain supply but demand for goods on its right hand side, so it seems that the difference between Keynes' identity and Lindahl's formulation is not so big after all.

However, Lindahl's microeconomic equation is derived from other parts of the system defining equlibrium on the factor markets, the cost principle and the determination of saving. Now, remember that Lindahl's assumption of constant returns to scale implies that the quantity sold of a good is determined from the demand side (supply is perfectly elastic). So the equilibrium conditions for each original factor market was not matched by corresponding equilibrium conditions for the goods markets. These equilibrium conditions were instead substituted for by the cost principle (one for each market). So we can say that the supply side is involved in the macroeconomic foundations of Lindahl's macroeconomic equlibrium condition. But the supply side only comes in indirectly, in a general equilibrium way.

\section{Capital theory and intertemporal analysis}

There are three main sources of inspiration for Lindahl's work on capital theory and intertemporal analysis. ${ }^{38}$ The first was Wicksell's (1893) formulation of the Austrian theory of capital in terms of a small general equilibrium model with two goods and two (original) factors of production. In a way this can be seen as a prototype for Lindahl's (1929a) model of stationary equilibrium.

Lindahl (1929a) started from Wicksell's, that is the Austrian theory of capital. This means that he conceived capital as earlier inputs of original factors of production. He did not work with inputs in the form of capital goods. However, Lindahl (1924 [1929, 32n]) did not only refer to Wicksell but also to Åkerman (1923).

\footnotetext{
${ }^{37}$ Lindahl: $(1939,142)$ only gives a reference to the definition of saving in Lindahl $(1939,329)$.

${ }^{38}$ Fisher (1907) might be added to the list given below. Landgren $(1960,126)$ and Laidler (1999, chapter 3) stress the influence of Fisher. Lindahl (1929a, 42-3) contains several references to Fisher; inter alia his concept of real capital.
} 
The second source of inspiration was Åkerman (1923), on which Wicksell (1923) wrote an extensive and penetrating review. The dissertation and Wicksell's review (including a mathematical appendix on the optimal durability of capital goods) introduced systematic analysis based on the Walrasian concept of capital in Sweden.

Lindahl's (1930) macroeconomic theory includes an aggregate consumer goods and an aggregate capital goods market. This indicates that Lindahl had deserted the Austrian theory of capital, which was the starting point for Lindahl (1929a), for the Walrasian approach where capital is analyzed in the form of capital goods, not as dated inputs according to the Austrians and Wicksell. In other words, the object of study is fixed, not circulating capital. ${ }^{39}$

It is however possible that Lindahl himself did not see any contradiction between the Austrian and the Walrasian point of view. Lindahl (1929a, 48-51 [1939, 296-301]) argued that the two points of view are essentially different ways of approaching the same phenomenon.

However, the exact interpretation is of little importance. The reason is that Lindahl pursued his macro analysis in a very intuitive way. He only derived one equation -the equilibrium condition for the aggregate consumption goods market -- while the effects via the other (implicit) macroeconomic relationships were not analyzed formally.

\footnotetext{
${ }^{39}$ There is an additional possible reason for Lindahl's separating of the aggregate goods market into an aggregate consumption goods and an aggregate investment goods market, namely the influence from Hawtrey, see Hansson (1982, 53-4) and Ohlin (1960). However, Hansson's $(1982,54)$ conclusion that "We have shown above that Ohlin's suggestion of an influence from Hawtrey is in fact correct, since there is a direct relation between the latter's idea of opposing consumers' outlay and consumer's income and Lindahl's formulation in [Lindahl (1929b)]" seems to be somewhat too strongly formulated. Lindahl $(1929 \mathrm{~b}, 10)$ criticized namely Hawtrey in the following way: " 'Consumers' outlay' during a certain period equals 'consumers' income' minus the increase of 'consumers' balances' during the same period, that is monetary balances that consumers keep in currency or in bank accounts. Capital investments (in other form than bank accounts) must consequently also be included in consumers' outlays." When comparing different versions of the equation of exchange Lindahl (1929b, 11) noted that "This equation differs from the previous [the Hawtrey equation] in that $\mathrm{P}_{4} \mathrm{~T}_{4}$ denotes consumers' outlays for consumption purposes during a certain period. The part of monetary income which is saved is thus not included." The criticism (which was also noted by Hansson 1982, 48) implies that Lindahl did not think that Hawtrey (1919) actually did separate demand for consumer goods from demand for capital goods. However, Lindahl might still have got the idea of analyzing equilibrium on the aggregate consumer goods market when studying Hawtrey (but not from Hawtrey). It should be added that Lindahl's (1929b) discussion (and the reference to Hawtrey) concerns the equation of exchange, not an equilibrium condition for the aggregate consumption goods market.
} 
Gunnar Myrdal's dissertation Prisbildningsproblemet och föränderligheten (Pricing and Change) from 1927 was the third source of inspiration to Lindahl's study of intertemporal and temporary equilibrium. In this book Myrdal developed a theory of the intertemporal planning of the firm. One of the arguments of the book was that predicted future changes in the environment of the firm would affect present actions ${ }^{40}$ -- compare the simultaneous equation system describing markets at different dates of Lindahl's intertemporal equilibrium. Lindahl had read the book in manuscript and his advice had influenced its final design. ${ }^{41}$ The book also contains an analysis of the importance of uncertainty and the possibilities to insure against it. This in turn is of importance for the need for monetary policy, compare the aim to diminish macroeconomic uncertainty.

\section{Assumptions about the monetary system}

In his monetary works during the 1920s Lindahl made different assumptions about the monetary system. In Lindahl (1929a) only relative prices are studied. But Lindahl (1929a, 72) considers the possibility that one of the goods is numeraire and variations of the level of prices can be studied in the restricted meaning that an index measure of the relative price of the numeraire increases or decreases. The development of the rate of interest then depends on which good has been chosen for unit of account. This discussion is not explicit in the English version, compare Lindahl (1939, 336).

In Means the basic assumption is that means of payments consist of interest bearing deposits in the bank. This is a system of pure inside money. Similarly to the case of pure inside money in Wicksell's cumulative process the price level is in neutral equilibrium. This also means that:

[...] predicted price level changes have no economic significance, since they do not influence relative prices of factors of production or consumption goods or the volume and composition of production. A change of the price level,

\footnotetext{
${ }^{40}$ Lindahl (1929a, 73 [1939, 337]).

${ }^{41}$ Lindahl also wrote a review of Myrdal's dissertation, see Lindahl (1929c). Unfortunately the review only contains a summary, not a critical discussion of the book.
} 
which is predicted in good time of all agents, can be taken into consideration in all contracts.

$$
\text { Lindahl (1930, } 16 \text { [1939, 148]) }
$$

Note that the assumption of pure inside money (used both by Wicksell and Lindahl) implies the absence of a monetary base and thus that there is no anchor for the price level. Here money is a financial asset the amount of which by definition is balanced by debts so that abstracting from distributional effects the real balance effect will be zero. The (initial) price level is determined by convention, which also is reflected by the fact that it rests in an indifferent equilibrium.

However, Lindahl (1930, 11 [1939, 141-42]) referring to Hayek (1928 [1984]) thought that the very fact that several periods are taken into consideration makes possible the determination if the development of the price level:

But if the theory is extended to cover dynamic situations, it must not only explain relative prices during each period but price relationships between different periods covered by the dynamic process as well. If we calculate an average of these "intertemporal" price relationships, we obtain an expression for the relative price level for different periods.

In a system of pure inside money there is no base for the quantity of money. The classical quantity theory of money cannot be used for explaining the price level. Therefore we cannot profitably supplement the equation system of Lindahl (1929a) with an equation that determines the price level. But he also discussed the possibility of outside money, one instant being the gold standard. According to Lindahl, even in this case the quantity theory of money would be no good theory of the price level. Lindahl (1930, 108-9) may be cited for a summary of Lindahl's view:

In spite of cash holding it consequently still holds that the price level is primarily determined by demand for and supply of consumption goods, and that the central bank can influence the price level by influencing these factors using methods indicated above. Firms and individuals adjust their cash 
holdings to the present price level. This means that the central bank does not directly have to regulate cash holdings. The common statement that the central bank influences the price level via a regulation of the quantity of money and that changes of the quantity of money is a cause of price level changes is therefore generally not true. Under the present assumptions the case will rather be the reverse: price level changes precede changes of cash holdings, the former cause the latter.

However, even if "the price level is primarily determined by demand for and supply of consumption goods", demand and supply could still be functions of real balances, compare Wicksell (1898a [1936, 39-40]). So the different monetary arrangements (cases of mixed inside-outside money) discussed by Lindahl could make a difference for the determination of the price level.

\section{The stability problem and the uniqueness of the price level}

The consequence of Lindahl's basic assumption -- pure inside money -- is that an increased price level (at constant relative prices) does not guarantee a new equilibrium. Wicksell (1898a) analyzed an analogous problem. In his "systematic analysis" of chapter 9 section B he assumed that different markets are equilibrated sequentially during the period so that first the factor markets and after that the goods markets are equilibrated. Since the expected price level of the current period is given by the price level of the previous period, factor price increases in connection with increased productivity make projected profits return to zero. In the next step the price level will increase as much as factor prices. Factor markets are first equilibrated and then goods markets. All this happens within the current period.

If instead of a sequence of partial equilibria, factor and goods markets are equilibrated simultaneously in the beginning of the current period, price expectations based on the price level of the previous period can no longer guarantee a finite price level. The reason is that the price level will be known at the same time, as factor prices are determined. In the case of pure inside money any price level might then be established. 
A possibility to get a new equilibrium price level in the current period is that the expectations about the price level in the next period are related to the price level of the previous period. A strong increase of the price level of the current period will then be related to a high expected real rate of interest (due to an expected fall of the price level in the next period). ${ }^{42}$ Lindahl $(1930,39-40 n$ [1939, 171-72n]) discussed this as a possibility:

The lower rate of interest consequently causes a price increase both for capital goods and consumption goods, but this price increase does not continue cumulatively, but for the case of capital goods reverts to a (small) price decrease. [...] For this to be correct, we have to assume, that pricing of capital goods $[. .$.$] is based on an expectation that consumption goods prices for future$ periods, when the capital goods mature into consumption goods, will be of the same low level or of an even lower level as before the decrease of the interest rate.

However, Lindahl choose to assume expectations about the next period to equal the price level of the current period. Not surprisingly, this led him to draw the conclusion that:

If there were no inertia in the interaction between pricing of capital and consumption goods, the price increase would evidently be like a rolling snowball.

Lindahl (1930, 40 [1939, 172])

A possible escape from this conclusion is in addition to assume outside money and like Wicksell let the real balances of the banks or of the public to indirectly or directly influence the aggregate demand for goods. Note that Lindahl unlike Wicksell (1898a [1936, 39-40]) did not discuss the real balance effect but Lindahl on the other hand

\footnotetext{
${ }^{42}$ For a discussion of the intertemporal substitution effect (effect via the expected price level of the next period and consequently the expected real rate of interest) and its connection with the real balance effect, see Grandmont (1983).
} 
noted that a fully expected inflation can produce lower real balances, see Lindahl $1924[1929,5 n])$.

Instead Lindahl's solution was to let some prices, mainly wage rates, be sticky. At unchanged relative prices this means that increases of the price level are determined by the price the inertia of which is the greatest. Alternatively, the stickiness of certain prices influences relative prices. Lindahl started from the latter assumption. Sticky wages in connection with an increase of the price level consequently lead to decreased real wages and to increased real wages in the opposite case. Since Lindahl assumed that the marginal propensity to save is higher for entrepreneurs than for workers, the redistribution of incomes caused by the change of the price level will cause the price increase to close the excess demand gap for consumption goods. Lindahl's assumption of sticky prices was not mainly motivated by realism but was, given his other assumptions, an analytical necessity.

However, the assumption of sticky wage rates implies a complication. By definition, under temporary equilibrium and given the expectations concerning the development during future periods the price system solves the system of (notional) excess demand functions for all markets for the current period. There is no need for the agents to have correct expectations of future prices, so surprises may happen in between periods. But the inertia of price movements might make the price system unable to solve the excess demand functions for the current period. The assumption of differential inertia may result in notional excess supply or excess demand in different markets. In the present case we would expect classical unemployment in connection with a decreased general price level. For discussions of classical and Keynesian unemployment, see Barro and Grossman (1976, chapter 2) and Malinvaud (1977, chapters 1-2).

Moreover, Lindahl (1930) in several places discussed how the properties of the system are effected by unemployment. But unemployment is not analyzed as an integral part of the properties of the system; it is rather introduced as an ad hoc assumption in order to discuss the effects of increased demand for goods on the price level if there are free resources to begin with. ${ }^{43}$

\footnotetext{
${ }^{43}$ Compare however the discussion of unemployment in the preliminary edition of 1929 and Hansen's (1981, 261-2) comments on that discussion.
} 
In sum, Lindahl (1930) did not analyze the possible imbalances caused by "wrong" relative prices. Already in Ends (65) Lindahl suggested that the existence of rigid prices might influence relative prices in connection with changes of the general price level. If monetary policy is based on the Davidson-Lindahl norm the distortion of real factor prices in connection with changes of general productivity will be minimized, however. This is a major argument for the Davidson-Lindahl norm. It also means that if shocks only are in the form of changes of general productivity, monetary policy following the norm will uphold temporary equilibrium for the extreme case of fixed nominal factor prices. For this case Lindahl's model is again consistent.

The assumption that some prices are sticky implies that price level changes will not be explosive within the period. Will then price level changes continue forever period by period or will the price level eventually reach a new stationary equilibrium? Lindahl thought the latter to be the case since disturbances that cause both price increases and capital accumulation successively adjust the capital stock to the lower rate of interest (Lindahl 1930, 46 [1939, 180-81]). This mechanism was already discussed by Wicksell (1903, 505). ${ }^{44} 45$

Expectations of inflation may on the other hand be affected (Lindahl 1930, 47 [1939, 182]), which might lead to a never-ending process. Wicksell $(1898 \mathrm{a}[1936,166])$ previously discussed expectations of inflation and referred to Fisher (1896), but was rather skeptic to expectations as an independent cause of price increases. Expectations of inflation were also discussed by Åkerman (1921) in a debate with Wicksell. Here Åkerman referred to Fisher (1907).

It is interesting to note that Lindahl's pupil Bent Hansen (1951) completely abstained from introducing a stabilizing mechanism in his model for open inflation. Instead he introduced the concept of quasi equilibrium where price and wage increases balance so that the real wage rate is constant.

\footnotetext{
${ }^{44}$ However, in his review of von Mises (1912) Wicksell (1914) argued against the possibility that the gap between the natural and the loan rate of interest could be filled via changes of the stock of capital and thereby by the natural rate.
} 


\section{Monetary analysis under temporary equilibrium - Lindahl, Hicks and later developments}

As noted in section 2 above, the origins of monetary analysis under temporary equilibrium is often wrongly attributed to Hicks. What is then the essential difference between the monetary analysis of Lindahl's Means and Hicks' Value and Capital? Hicks $(1985,69)$ described it in the following way: "The place where I myself departed from Lindahl (and so moved in the direction of Keynes) was with respect to the things which I allowed to happen within the single period. According to Lindahl (I think one may safely say) the expectations that rule in the current period are based upon past experience: they are uninfluenced by what happens in the market during the current period itself. It is this which enables them to form a link between periods -- a link, which, once we allow them to be based on current experience, is bound to disappear. It was because I did allow them to be influenced (even, on occasion, to be chiefly influenced) by current experience, that my model was moved in a "quasistatic' direction."

When Hicks $(1985,66)$ described the cumulative process using the Lindahl method he consequently assumed that "money prices, which in period $(t)$, are expected to rule in all future periods $(t+1, t+2, \ldots)$ are the money prices that did actually rule in period $t-1 . "$

However, the expectation assumption which Hicks alluded to Lindahl was actually the assumption used by Wicksell (1898 [1936]) in part B of chapter 9 where Wicksell made a "systematic exposition" of his theory. Instead Lindahl's expectational assumption was essentially the same as that used by Hicks. So what did Hicks' own contribution amount to?

The relevant discussion in Hicks' (1939) can be found in chapters XX and XXI. The additions in the second edition from 1946 can be found in Additional Note B. In contrast to Lindahl, Hicks did not discuss monetary policy but concentrated on the

\footnotetext{
${ }^{45}$ As mentioned above, Lindahl did not analyze the implications of two alternative mechanisms for convergence, the real balance effect or internal and external drain. These mechanisms were discussed in Wicksell (1898a).
} 
theoretical issues. The essential addition which Hicks made to Lindahl's analysis was a much more clear discussion of the stability problem. In the 1939 edition in following Lindahl Hicks noted three possible ways to get a finite price level and to avoid instability.

First of all he explicitly noted the possibility that effects on the wealth distribution of a change of the price level might affect stability.

Secondly, by using his concept of elasticity of expectations Hicks could discuss expectations in a more general way than Lindahl. In the event of a positive demand chock an increase of the price level could depress demand if the agents thought that the price level would fall back during the next period. This presupposes an elasticity of expectations less than one. The effect of this is to increase the expected real rate of interest between the present and the next period. The nominal rate of interest is assumed to be constant.

Thirdly, if the elasticity of expectations with respect to the price level equals unity (Lindahl's case) some sort of price rigidity would be required for stability. Like Lindahl Hicks discussed the possibility of rigid prices, for example rigid wages.

Hicks made three important additions to Lindahl's analysis of the rigidity issue. First he noted that disequilibrium in one market (analyzed in the Marshallian way as a gap between the supply and demand price, respectively) might affect demand and supply in other markets and thereby indirectly the other prices. Hicks discussion of these spill-over effects was based on the substitutability and complementarity between the various goods in a way that forebode the Tobin-Houtakker theory of rationing, compare Tobin and Houthakker (1950-51) and Tobin (1952).

Hicks' second addition to Lindahl's analysis of price rigidity concerns the potential effects on production and employment of wage rigidity. Here Hicks referred to Keynes. Wage rigidity might imply that aggregate demand chocks would have small impacts on the price level but large effects on production and employment. 
Hicks consequently discussed both of the two basic building blocks in Barro and Grossman's (1976) and Malinvaud's (1977) attempt to build macroeconomics similar to the Keynesian system on microeconomic foundations: price rigidity in combination with rationing and spill-over effects. But he did not bring the two building blocks together like the economists mentioned above.

Hicks third addition to Lindahl's discussion of price rigidity concerns the reasons for rigidity itself:

If all elasticities of expectations are unity, the stability of the system can only be maintained by the existence of rigid wage-rates; but if all elasticities of expectations are unity, why should wage-rates be rigid? It cannot be maintained that wage-rates are fixed at a particular level in money terms because wage-earners want so much money for its own sake; the reason why money wages are rigid must be because those people who fix wages have some degree of confidence in a stable value of money -- that is to say, because they have fairly inelastic price-expectations. So long as they retain the view that a certain level of prices is 'normal', it is perfectly rational for them to fix wage-rates in money terms at a level which seems to them 'fair' in relation to this 'normal' price-level. But that gives us no justification for assuming that money wages would remain rigid if the sense of normality was lost.

Hicks $(1946,271)$

The main addition in the second edition of Value and Capital concerns the possible stabilizing effects via real balances (called income effects by Hicks). Hicks was aware of the fact that only distributional effects will occur in a "pure credit economy" (pure inside money).

During the 1970s and 1980s the temporary equilibrium method as a basis for monetary analysis was further developed by a number of principally French economists. The development is summarized in Grandmont (1977; 1982; 1983 and 1987) and concerned both the microeconomics of general temporary equilibrium as well as temporary equilibrium applied to monetary issues. 
The development implies a more precise analysis in comparison to that of Hicks and Lindahl. First of all, what mechanism coordinates the plans of the agents during the first period? If we have flexible prices the price system will do it (temporary competitive equilibrium). In the case of at least some rigid prices, both prices and rationing restrictions (temporary equilibrium with quantity rationing) coordinate the actions of the agents. In the latter case the rationing restrictions must be known to the agents and they adjust to the mixed price-quantity system. ${ }^{46}$

Secondly, monetary analysis under temporary equilibrium was further developed. The existence of a monetary economy with fiat money and its stability properties were examined. Here the analysis is focused on the intertemporal substitution effect (effect via the expected price level of the next period and consequently the expected real rate of interest) as well as the real balance effect, compare Grandmont (1983).

To sum up, both the work on temporary equilibrium and its application on monetary problems done by Hicks and that done during the 1970s and 1980s are directly (in Hicks case) or indirectly based on Lindahl's formulation of the problem. The analytical formulations were successively made more precise, but with the exception of Hicks' discussion of spill-over effects, the basic questions were those originally formulated by Lindahl.

\section{Summary and conclusion}

As stressed in the introduction, Lindahl played a central role in the transmission of the Wicksellian tradition in Sweden. Lindahl's monetary analysis was much influenced by that of Wicksell. Lindahl $(1930,121$ [1939, 245]) stressed the connection between his own analysis and that of Wicksell by pointing out that "changes of the price level as well as of relative prices should be explained by the relationship between demand and supply of goods." This means that the same sort of mechanisms should be used to explain monetary and "real" phenomena. Equation (1) of Means reflects this. ${ }^{47}$

\footnotetext{
${ }^{46}$ Compare Barro and Grossman (1976), Malinvaud (1977) and Benassy (1982).

${ }^{47}$ The citation also reflects Lindahl's critical attitude to the quantity theory of money.
} 
Secondly, both Wicksell and Lindahl analyzed the case of pure inside money. But whereas Wicksell saw this as an extreme case on one end of a scale with pure outside money on the other end, this was the main case for Lindahl.

Thirdly, both Wicksell and Lindahl based the real part of their monetary analyses on microeconomic foundations in the form of capital theory formulated within general equilibrium models.

Lindahl's monetary analysis consequently started from that of Wicksell. But Lindahl did not follow Wicksell all the way. The most important example is Wicksell's focus on the gap between the natural ${ }^{48}$ and the loan rate of interest. At the same time Lindahl extended the Wicksellian analysis in several directions.

Ohlin (1960) pointed out that Lindahl developed Wicksell's theory of money in four respects: a better terminology, expectations were more systematically analyzed, fiscal and wage policy was included in the analysis and finally Lindahl dropped the assumption of full employment. Ohlin wrote this in 1960 when the Keynesian perspective was natural (of course he also included Lindahl's work after 1930, which does not concern us here).

The discussion of fiscal and wage policy was not very developed in Means. This also holds for the assumption of less than full employment. The assumption of sticky prices and factor prices -- especially wage rates -- was rather made for analytical reasons (to get a finite rate of change of the aggregate price level). What from a Keynesian perspective could be seen as a progressive trait in his analysis was rather an effect of his main assumption of pure inside money.

Today one would put more stress on the analytical innovations introduced by Lindahl:

1. A norm for monetary policy implicitly based on microeconomics.

\footnotetext{
${ }^{48}$ In Lectures II Wicksell had substituted the normal rate of interest for the natural rate. The normal rate has according to Wicksell the following properties: 1 . A normal loan rate of interest corresponds to the natural rate of interest 2 . The normal rate of interest is characterized by equilibrium between the supply of and the demand for saving ( $\mathrm{S}=\mathrm{I}) 3$. The normal rate of interest implies a constant price level.
} 
2. Development of the concept of temporary equilibrium for analyzing macroeconomic problems.

3. Using the Walrasian approach to the theory of capital to introduce a small macroeconomic model with an aggregated consumption goods market and an aggregated capital goods market.

4. The analysis of the uniqueness and stability problems of the price level by assuming rigidities of some nominal prices (mainly wages). The solution might not be elegant, but it was a result of Lindahl's attitude to theoretical work, to carefully derive the consequences of a set of assumptions about the economy and to accept even uncomfortable conclusions.

However, in many cases it was not so much a question of achieved results as the intellectual attitude to economic research where Lindahl set the standard. Lindahl's open attitude paved the way for research by other Swedish economists. The main example is Myrdal's development of monetary equilibrium and the more general analysis of pricing than under temporary equilibrium. Lindahl himself further developed monetary analysis in the 1930s on the basis of Myrdal's results. But this is another story. 


\section{$\underline{\text { Literature }}$}

Bailey, R. E. 1976. On the Analytical Foundations of Wicksell's Cumulative Process. The Manchester School of Economic and Social Studies 44.1:52-71.

Barro, Robert and Herschel Grossman. 1976. Money, Employment and Inflation. Cambridge: Cambridge University Press.

Bianovsky, Mauro. 1995. Wicksell's business cycle, The European Journal of the History of Economic Thought, 2.2: 375-411.

Bianovsky, Mauro. 1998. Wicksell on Deflation in the Early 1920s, History of Political Economy, 30.2: 219-75.

Benassy, Jean-Pascal. 1982. The Economics of Market Disequilibrium. New York: Academic Press, INC.

Brisman, Sven. 1922. Räntan vid direkt inflation (The Rate of Interest at Direct Inflation), Ekonomisk Tidskrift, 24: 1-4.

Cassel, Gustav. 1918. Theoretische Sozialökonomie. Leipzig: C.F. Wintersche Verlagshandlung.

Chiodi, Guglielmo. 1991. Wicksell's Monetary Theory. New York: St. Martin's Press.

Davidson, David. 1899. Review of Knut Wicksell: Geldzins und Güterpreise, Ekonomisk Tidskrift, 1: 233-40.

Davidson, David. 1906. Något om "penningens värde" (A Note on the "The Value of Money”), Ekonomisk Tidskrift, 8: 460-68.

Davidson, David. 1919. Några teoretiska frågor (Some theoretical questions), Ekonomisk Tidskrift, 21: 231-59.

Davidson, David. 1922. Till frågan om penningvärdets reglering under kriget och därefter (On the regulation of the value of money during and after the war), Ekonomisk Tidskrift, 24: 89-114. [Part 1]

Davidson, David. 1923. Till frågan om penningvärdets reglering under kriget och därefter (On the regulation of the value of money during and after the war), Ekonomisk Tidskrift, 25: 191-234. [Part 2]

Dimand, R.W. 1986. The Macroeconomics of the Treatise on Money, Eastern Economic Journal, 12: 431-41.

Fernholm, Tor. 1960. Idéutveckling, ekonomisk politik och ekonomisk teori (Development of Ideas, Economic Policy and Economic Theory). Ekonomisk Tidskrift 62: 161-184. 
Fisher, Irving. 1896. Appreciation and Interest. New York: The Macmillan Company.

Fisher, Irving. 1906. The Nature of Capital and Income. New York: Macmillan.

Fisher, Irving. 1907. The Rate of Interest. New York: Macmillan.

Fisher, Irving. 1930. The Theory of Interest. New York: Macmillan.

Fregert, Klas. 1993. Erik Lindah's Norm for Monetary Policy, in Jonung (1993).

Fregert, Klas. 1994. Wage Contracts, Policy Regimes and Business Cycles, Lund Economic Studies, Lund.

Friedman, Milton. 1969. The Optimum Quantity of Money and Other Essays. Chicago: Aldine Publishing Company.

Grandmont, Jean Michael. 1974. On the Short Run Equilibrium in a Monetary Economy. In Jaques Dreze (editor). Allocation under Uncertainty, Equilibrium and Optimality. New York: Macmillan.

Grandmont, Jean Michael. 1977. Temporary General Equilibrium Theory. Econometrica, 45.3: 535-72.

Grandmont, Jean Michael. 1982. Temporary General Equilibrium Theory. In Kenneth J. Arrow and Michael D. Intrilligator (editors). Handbook of Mathematical Economics, Volume II. Amsterdam: Elsevier Science Publishers.

Grandmont, Jean Michael. 1983. Money and Value. Cambridge: Cambridge University Press.

Grandmont, Jean Michael. 1987. Temporary equilibrium. In John Eatwell, Murray Milgate and Peter Newman (editors). The New Palgrave Dictionary of Economics. London: Macmillan.

Grandmont, Jean Michael and Yves Younes. 1977. On the Role of Money and the Existence of a Monetary Equilibrium. Review of Economic Studies, 39: 355-72.

Gurley, John G. and Shaw, Edward S. 1960. Money in a Theory of Finance.

Washington, D. C.: The Brookings Institution.

Hammarskjöld, Dag. 1944. Den svenska diskussionen om penningpolitikens mål, Studier i Ekonomi och Historia tillägnade Eli F. Heckscher på hans 65te födelsedag. Translated as "The Swedish discussion on the Ends of Monetary Policy", International Economic Papers, No 5, London: Macmillan, 1955.

Hansen, Bent. 1951. A Study in the Theory of Inflation. London: George Allen and Unwin. 
Hansen, Bent. 1955. Finanspolitikens ekonomiska teori. Stockholm: Statens Offentliga Utredningar 1955:25. Translated as The Economic Theory of Fiscal Policy. Lund: Studentlitteratur, 1967.

Hansen, Bent. 1981. Unemployment, Keynes, and the Stockholm School. History of Political Economy, 13.2: 156-77.

Hansson, Björn A. 1982. The Stockholm School and the Development of Dynamic Method. London: Croom Helm.

Hansson, Björn A. 1987. Forced Saving. In John Eatwell, Murray Milgate and Peter Newman (editors). The New Palgrave Dictionary of Economics. London: Macmillan.

Hawtrey, Ralph G. 1919. Currency and Credit. London: Longmans.

Hayek, Friedrich A. 1928. Das intertemporale Gleichgewichtssystem der Preise und die Bewegungen des Geldwertes. Weltwirtschaftliches Archiv, XX: 33-79. Translated as Intertemporal Price Equilibrium and Movements in the Value of Money, in Hayek, F.A. (1984). Money Capital \& Fluctuations. Edited by R. McCloughry. London, Melbourne and Henley: Routledge \& Kegan Paul.

Hayek, Friedrich A. 1929. Geldtheorie und Konjunkturtheorie. Wien: Hölder-PichlerTempsky. Translated as Monetary Theory and the Trade Cycle. London: Jonathan Cape, 1933. Reprinted 1975 by Augustus M. Kelley Publishers, Clifton.

Heckscher, Eli F. 1951. David Davidson. Ekonomisk Tidskrift 51.3: 127-60.

Henriksson, Rolf G. 1991. The Political Economy Club and the Stockholm School, 1917-1951, in Jonung 1991.

Herz, Ulrich. 1959. Till Erik Lindahls minne (To the Memory of Erik Lindahl). Ekonomisk Tidskrift 61: 199-200.

Hicks, John. 1939. Value and Capital. First edition. Oxford: Oxford University Press.

Hicks, John. 1946. Value and Capital. Second edition. Oxford: Oxford University Press.

Hicks, John. 1965. Capital and Growth. Oxford: Oxford University Press.

Hicks, John. 1985. Methods of Dynamic Economics. Oxford: Oxford University Press Jonung, Lars, ed. 1991. The Stockholm School of Economics Revisited. Cambridge: Cambridge University Press.

Jonung, Lars, ed. 1991. The Stockholm School of Economics Revisited. Cambridge: Cambridge University Press.

Jonung, Lars, ed. 1993. Swedish Economic Thought. London and New York: Routledge. 
Knight, Frank H. 1921. Risk, Uncertainty and Profit. Boston and New York: Houghton Mifflin Company, The Riverside Press Cambridge.

Keynes, John Maynard. 1923. A Tract on Monetary Reform. Reprinted in 1971 as Volume IV of The Collected Works of John Maynard Keynes. Cambridge: Macmillan St Martin's Press.

Keynes, John Maynard. 1930. A Treatise on Money. The Pure Theory of Money. (1930). Reprinted in 1971 as Volume V of The Collected Works of John Maynard Keynes. Cambridge: Macmillan St Martin's Press.

Laidler, David. 1991. The Golden Age of the Quantity Theory. New York: Philip Allan.

Laidler, David. 1998. The Wicksell Connection, the Quantity Theory and Keynes, in Streissler (1998).

Laidler, David. 1999. Fabricating the Keynesian Revolution. Cambridge: Cambridge University Press.

Landgren, Karl-Gustaf . 1960. Den 'nya ekonomien' i Sverige (The 'New Economics' in Sweden). Dissertation, University of Uppsala.

Leijonhufvud, Axel. 1991. 'Roundtable discussion', in Jonung (1991).

Lindahl, Erik. 1919. Die Gerechtigkeit der Besteuerung. Dissertation, University of Lund.

Lindahl, Erik. 1924. Penningpolitikens mål och medel (Ends and Means of Monetary Policy). Reprinted in 1929 with the title Penningpolitikens mål (Ends of Monetary Policy). Malmö: Förlagsaktiebolaget.

Lindahl, Erik. 1925. Den korta kreditens nationalekonomiska betydelse (The Importance of Short Term Credit in Economics). Ekonomisk Tidskrift 27: 221 - 244.

Lindahl, Erik. 1929a. Prisbildningsproblemets uppläggning från kapitalteoretisk synpunkt. Ekonomisk Tidskrift 31: 31-81. Translated into English and included in Lindahl (1939).

Lindahl, Erik. 1929b. Om förhållandet mellan penningmängd och prisnivå (On the Relationship between the Quantity of Money and the Price Level). Uppsala Universitets Årsskrift 1929. Juridiska fakultetens minneskrift. 1-18. Uppsala: Almqvist \& Wicksells Boktryckeri AB.

Lindahl, Erik. 1929c. Review of Dynamic Pricing (Prisbildningsproblemet och föränderligheten) by Dr Gunnar Myrdal. Economic Journal 39:89-91.

Lindahl, Erik. 1930. Penningpolitikens medel (Means of Monetary Policy). Malmö: Förlagsaktiebolaget. Partly translated into English and included in Lindahl (1939). 
Lindahl, Erik. 1939. Studies in the Theory of Money and Capital. London: George Allen \& Unwin Ltd.

Lindahl, Gertrud. 1960. Erik Lindahl och 30-talets sysselsättningsproblem (Erik

Lindahl and employment policy during the 1930s). Ekonomisk Tidskrift 62: 296-300.

Lucas, Robert E. 1972. Expectations and the Neutrality of Money. Journal of Economic Theory 4: 103-24.

Lundberg, Erik. 1930. Om begreppet ekonomisk jämvikt. Ekonomisk Tidskrift 32: 133-60. Translated as On the Concept of Economic Equilibrium. Translated in Lundberg, E. (1995). Studies in Economic Instability and Change. Kristianstad: SNS Förlag. Edited by Rolf G. H. Henriksson.

Lundberg, Erik. 1980. Lindahl, Erik Robert, Svenskt Biografiskt Lexikon, Vol 23, pp. 193-6. Translated in Lundberg, E. (1995). Studies in Economic Instability and Change. Kristianstad: SNS Förlag. Edited by Rolf G. H. Henriksson.

Magnusson, Lars. 1991. Custav Cassel, popuralizer and enigmatic Walrasian. In Sandelin (1991).

Malinvaud, Edmond. 1977. The Theory of Unemployment Reconsidered. Oxford: Basil Blackwell.

Mason, Will E. 1982. The Labor Theory of Value and Gold: Real and Nominal Standards of Value - and Implications for the Current Reconsideration of the Gold Standard. History of Political Economy 14.4: 541-58.

Milgate, Murray. 1979. On the Origin of the Notion of "Intertemporal Equilibrium", Economica 46: 1-10.

von Mises, Ludwig. 1912. Theorie des Geldes und der Umlaufsmittel. München and Leipzig: Duncker \& Humblot. Translated by H.E. Batson as The Theory of Money and Credit, Jonathan Cape, London 1934. Reprinted 1953 by Yale University Press, New Haven, CT.

Muth, John F. 1961. Rational Expectations and the Theory of Price Movements. Econometrica 29: 315-35.

Myhrman, Johan. 1991. The Monetary Economics of the Stockholm School. In Jonung (1991).

Myrdal, Gunnar. 1927. Prisbildningsproblemet och föränderligheten (The Pricing Problem and Change). Uppsala and Stockholm: Almqvist \& Wicksells förlag.

Myrdal, Gunnar. 1931. "Om penningteoretisk jämvikt. En studie i den 'normala räntan' i Wicksells penninglära". Ekonomisk Tidskrift 33: 191-302. 
Myrdal, Gunnar. 1933. "Der Gleichgewichtsbegriff als Instrument der geldtheoretischen Analyse", in Hayek, F von (red), Beiträge zur Geldtheorie. Wien: Verlag von Julius Springer.

Myrdal, Gunnar. 1939. Monetary Equilibrium. London: Hodge. Reprinted by Auigustus M. Kelly, New York 1965.

Ohlin, Bertil. 1937a. Some Notes on the Stockholm Theory of Savings and Investments I. Economic Journal 47: 53-69.

Ohlin, Bertil. 1937b. Some Notes on the Stockholm Theory of Savings and Investments II. Economic Journal 47: 121-140.

Ohlin, Bertil. 1960. Erik Lindahl -- några minnesord (Erik Lindahl -- A few Words of Memory). Ekonomisk Tidskrift 62: 1-4.

Patinkin, Don. 1965. Money, Interest and Prices. 2nd Edition. New York: Harper \& Row, Publishers.

Petersson, Jan. 1987. Erik Lindahl och stockholmsskolans dynamiska metod (Erik Lindahl and the Dynamic Method of the Stockholm School). Lund:

Universitetsförlaget Dialogus AB.

Petersson, Jan. 1989. Erik Lindahl. Ekonomisk Debatt 17: 557-570.

Petersson, Jan. 1991. The late development of the Stockholm School and the criticism of Johan Åkerman. In Jonung (1991).

Sandelin, Bo (editor). 1991. The History of Swedish Economic Thought. London and New York: Routledge.

Schiller, Robert J. 1978. Rational Expectations and the Dynamic Structure of Macroeconomic Models - a Critical Review. Journal of Monetary Economics 4: 1-44.

Schumpeter, Joseph A. 1954. History of Economic Analysis. New York: Oxford University Press.

Selgin, George. 1995. The "Productivity Norm" versus Zero Inflation in the History of Economic Thought. History of Political Economy 27.4: 705-35.

Selgin, George. 1999. Hayek versus Keynes on How the Price Level Ought to Behave. History of Political Economy 31.4: 699-721.

Siven, Claes-Henric. 1985. The End of the Stockholm School. The Scandinavian Journal of Economics 87: 577-93.

Siven, Claes-Henric. 1997. Capital Theory and Equilibrium Method in Wicksell's Cumulative Process, History of Political Economy 29: 201-17. 
Siven, Claes-Henric. 1998. Two Early Swedish Debates about Wicksell's Cumulative Process, The European Journal of the History of Economic Thought 5: 120-39.

Statistics Sweden. 1993. Konsumentprisindextal 1914-1992.

Steiger, Otto. 1971. Studien zur Entstehung der Neuen Wirtschaftslehre in Schweden (Studies in the Origin of the New Economic Theory in Sweden). Berlin: Duncker \& Humblot.

Steiger, Otto. 1987a. Lindahl, Erik Robert. In John Eatwell, Murray Milgate and Peter Newman (editors). The New Palgrave Dictionary of Economics. London: Macmillan.

Steiger, Otto. 1987b. Monetary Equilibrium. In John Eatwell, Murray Milgate and Peter Newman (editors). The New Palgrave Dictionary of Economics. London: Macmillan.

Streissler, Erich W. 1998. Studien zur Entwicklung der ökonomischen Theorie XVIII. Berlin: Duncker \& Humblot.

Svennilson, Ingvar. 1960. Erik Lindahl 1891-1960. Kungl. Vetenskapssocietetens Årsbok. Uppsala.

Thomas, Brinley. 1935. The Monetary Doctrines of Professor Davidson, Economic Journal, 45: 36-50.

Tobin, James. 1952. A Survey of the Theory of Rationing. Econometrica 20.4: 52153.

Tobin, James and H. S. Houthakker. 1950-51. The Effects of Rationing on Demand Elasticities. Review of Economic Studies 18: 140-53.

Trautwein, Hans-Michael. 1998. The Wicksell Connection, the Quantity Theory and Keynes: Comment, in Streissler (1998).

Turvey, Ralph. 1960. Erik Lindahl. Ekonomisk Tidskrift 62: 5-8.

Uhr, Carl G. 1960. Economic Doctrines of Knut Wicksell. Berkeley: University of California Press.

Uhr, Carl. 1975. Economic Doctrines of David Davidson. Uppsala: Almqvist \& Wicksell International.

Velupillai, Kumaraswamy. 1988. Some Swedish Steping Stones to Modern Macroeconomics. Eastern Economic Journal 14: 87-98.

Walsh, Correa M. 1903. The Fundamental Problem of Monetary Science. New York and London: Macmillan \& Co. Ltd. 
Wicksell, Knut. 1893. Über Wert, Kapital und Rente. Jena: Gustav Fisher. Translated by S.H. Frohwein as Value, Capital and Rent, George Allen \& Unwin Ltd, London 1954. Reprinted 1970 by Augustus M. Kelley Publishers, New York.

Wicksell, Knut. 1896. Finanztheoretische Untersuchungen nebst Darstellung und Kritik des Steuerwesens Schwedens. Jena: Gustav Fischer.

Wicksell, Knut. 1898a. Geldzins und Güterpreise. Jena: Gustav Fisher. Translated by R.F. Kahn as Interest and Prices, Macmillan, London 1936. Reprinted 1965 by Augustus M. Kelley Publishers, New York.

Wicksell, Knut. 1898b. Penningräntans inflytande på varuprisen. Lecture at the Swedish Economic Association, April 14 ${ }^{\text {th }}, 1898$. Translated as Influence of rate of interest on commodity prices, in Wicksell (1958).

Wicksell, Knut. 1901. Föreläsningar i nationalekonomi, första delen, Stockholm. Translated by E. Classen as Lectures on Political Economy, Volume One: General Theory, Routledge \& Sons, Ltd., 1934. Reprinted 1977 by Augustus M. Kelley Publishers, New York.

Wicksell, Knut. 1903. Den dunkla punkten i penningteorien (The Obscure point in the Theory of Money), Ekonomisk Tidskrift, 5: 485-507.

Wicksell, Knut. 1904. Mål och medel i nationalekonomien. Ekonomisk Tidskrift, 6: 457-74. Translated as Ends and Means in Economics, in Wicksell (1958).

Wicksell, Knut. 1906. Föreläsningar i nationalekonomi, andra delen: Om penningar och kredit, Stockholm. Translated by E. Classen as Lectures on Political Economy, Volume Two: Money, George Routledge \& Sons, Ltd., 1935. Reprinted 1978 by Augustus M. Kelley Publishers, New York.

Wicksell, Knut. 1908. Penningvärdets stadgande, ett medel att förebygga kriser. Ekonomisk Tidskrift 10.2: 207-14. Translated as Stabilizing the Value of Money--A Means of Preventing Crises, in Wicksell (1999).

Wicksell, Knut. 1914. Review of Ludwig von Mises, Theorie des Geldes und der Umlaufsmittel. Zeitschrift für Volkswirtschaft, Sozialpolitik und Verwaltung.

Translated in Wicksell (1999).

Wicksell, Knut. 1922. Preface to the 1922 German edition of volume two (Money and Credit) of the Lectures. Translation 1986 by D. Plant. Political Economy 2.2:191-97.

Wicksell, Knut. 1923. Realkapital och kapitalränta. Review of Åkerman (1923). Ekonomisk Tidskrift, 25: 145-80. Reprinted in the volume containing the English translation of Wicksell (1901).

Wicksell, Knut. 1958. Selected Papers on Economic Theory. Edited by Erik Lindahl and translated by Reginald S.Stedman, Sylva Gethin and Alan Williams. George Allen \& Unwin. Reprinted 1969 by Augustus M. Kelley Publishers, New York. 
Wicksell, Knut. 1999. Selected Essays in Economics, Volume II. Edited by Bo Sandelin and translated by Timothy Chamberlain. London and New York: Routledge.

Yohe, William P. 1962. A Note on Some Lesser-Known Works of Erik Lindahl. Canadian Journal of Economics and Political Science, 28.2: 274-80.

Åkerman, Gustaf . 1921. Inflation, penningmängd och ränta (Inflation, Quantity of Money and Interest Rate), Ekonomisk Tidskrift, 23: 143-62.

Åkerman, Gustaf . 1923. Realkapital und Kapitalzins. Dissertation, University of Lund.

Östlind, Anders. 1945. Svensk samhällsekonomi 1914-1922 (Swedish Economy 19141922). Stockholm: Svenska Bankföreningen. 